\title{
KEPUTUSAN PETANI TERHADAP PENANGANAN PASCAPANEN JAMBU AIR DI KABUPATEN DEMAK
}

\author{
Farmers' Decisions on Post-Harvest Handling of Water Apple in Demak Regency \\ Triyono* dan Nur Rahmawati \\ Program Studi Agribisnis Fakultas Pertanian Universitas Muhammadiyah Yogyakarta, \\ Jl. Brawijaya Tamantirto Kasihan Bantul Yogyakarta
}

Alamat korespondensi: triyono@umy.ac.id

\begin{abstract}
ABSTRAK
Kabupaten Demak merupakan salah satu sentra jambu air di Jawa Tengah. Produksi jambu air di Kabupaten Demak mempunyai karakteristik mudah rusak dan berisiko rugi jika terjadi panen raya. Penelitian ini bertujuan mengetahui faktor-faktor yang mempengaruhi keputusan petani terhadap penanganan pasca panen jambu air serta peluang keputusan penanganannya. Sampel penelitian ini diambil sebanyak 72 petani dari tiga gapoktan yaitu Sekar Tani, Sido Maju, dan Tani Sentosa. Analisis data menggunakan metode analisis regresi logistik binomial. Hasil analisis menunjukkan bahwa keputusan petani untuk melakukan penanganan pascapanen dipengaruhi oleh umur, harga dan pekerjaan luar usahatani (off farm). Umur petani yang relatif sudah lanjut usia menyebabkan penurunan peluang keputusan untuk melakukan penanganan pascapanen. Harga dan akses jaringan kerjasama memungkinkan peningkatan peluang keputusan petani untuk melakukan penanganan pascapanen. Oleh karena itu penting dilakukan pelatihan bagi generasi muda untuk pengelolaan usahatani jambu air yang lebih baik terutama penanganan pascapanen.
\end{abstract}

Kata kunci: jambu air, keputusan petani, pascapanen

\begin{abstract}
Demak Regency is one of the water apples producing centers in Central Java. The production of water apple in Demak Regency has the characteristics of being easily damaged and at risk if there is a big harvest. This study aims to determine the factors that influence farmers' decisions on post-harvest handling of water apple. The samples of this research were 72 farmers from three Gapoktan namely Sekar Tani, Sido Maju, and Tani Sentosa. Data analysis using binomial logistic regression analysis method. The results of the analysis show that the farmers' decision to carry out post-harvest handling is influenced by variables of age, price and off-farm work. The relatively old age of the farmers causes a decrease in the opportunity for decisions to take post-harvest handling. Prices and access to cooperative networks allow increased opportunities for farmers' decisions to handle postharvest handling. Therefore, it is important to conduct training for the younger generation for better management of water apple farming, especially post-harvest handling.
\end{abstract}

Keywords: farmer's decision, post-harvest, water apple.

\section{PENDAHULUAN}

Salah satu komoditas tanaman hortikultura yang memiliki potensi ekonomi adalah jambu air. Sebagaimana nama buahnya, jambu air ini memiliki banyak sekali kandungan air di dalam buahnya, bisa mencapai $87 \%$ dari buahnya. Jambu air ini merupakan salah satu tanaman buah khas Nasional Indonesia, sehingga jambu air banyak ditanam di Indonesia (Cahyono, 2010). Persebaran produksi jambu air tersebar di seluruh Indonesia. Salah satu provinsi yang banyak menghasilkan jambu air adalah Jawa Tengah yakni Kabupaten

Demak sebagai sentranya.

Produksi jambu air di Kabupaten Demak pada 2015 adalah sebesar 99.801 kuintal, dan produksi jambu air di seluruh 
Jawa Tengah adalah sebesar 199.238 kuintal (Badan Pusat Statistik, 2015). Hal ini berarti produksi jambu air terbesar di Jawa Tengah terdapat di Kabupaten Demak dengan persentase sebesar 50,1 \%. Kemudian produksi jambu air di Kabupaten Demak pada tahun 2016 mengalami peningkatan, yang jumlahnya sebesar 104.076 kuintal, serta pada tahun 2017 produksi jambu air di Kabupaten Demak sebanyak 101.275 kuintal (BPS, 2017). Kondisi produksi relatif stabil yakni produksi pada tahun 2018101.274 kuintal dan pada tahun 2019 produksi mencapai 125.111 kuintal (Badan Pusat Statistik, 2020).

Seperti halnya komoditas hortikultura pada umumnya, jambu air di Kabupaten Demak mempunyai karakteristik mudah rusak dan cukup berisiko terjadi kerugian apabila petani kekurangan tenaga dan modal untuk proses penanganan pasca panen. Dalam pengolahan jambu air yang mempunyai karakteristik tersebut, penanganan pasca panen yang dilakukan semestinya dan sesuai dengan SOP (Standard Operasional Prosedure) meliputi pengumpulan, pembersihan, sortasi, grading, pengepakan, dan pelabelan jambu air (Dinas Pertanian Kabupaten Demak, 2010). Namun, dalam keadaan produksi jambu air yang berlimpah, penanganan pasca panen yang dilakukan kadang tidak sesuai dengan penanganan pasca panen yang semestinya dilakukan, seperti tidak adanya sortasi dan grading. Kondisi ini tentu akan berdampak pada kualitas dan harga produksi jambu air yang dihasilkan. Penanganan pasca panen yang tidak tepat akan menurunkan kualitas produksi sehingga harga jambu kemungkinan turun apalagi pada saat panen raya. Meskipun produksi jambu meningkat, tetapi apabila harganya rendah tentu akan mempengaruhi keberhasilan usahatani jambu air.

Keberhasilan produksi jambu air dipengaruhi oleh faktor luas lahan, pupuk, penggunaan insektisida, dan tenaga kerja (Setiarini, 2015). Oleh karena itu petani sebagai manajer sekaligus tenaga kerja memiliki peran penting terhadap keberhasilan usahatani yang dijalankannya. Sebagai manajer, petani berperan dalam pengambilan keputusan terhadap berbagai alternatif pilihan sumberdaya dan teknologi yang akan digunakan dalam menjalankan usahataninya. Usahatani yang bisa dipandang sebagai kegiatan untuk memaksimalkan keuntungan, maka manajer perusahaan dituntut untuk mengambil keputusan dengan memperhitungkan nilai dan harga perusahaan (Febrianti, 2012).

Keputusan adalah suatu pilihan yang diambil dari beberapa pilihan yang tersedia. Keputusan yang baik dan tepat terhadap sasarannya adalah keputusan yang mempertimbangkan berbagai sistem pendukung keputusan. Sistem pendukung 
keputusan tersebut terdiri atas tiga fase yaitu, pertama proses penelusuran sebuah masalah dan mencari data, kedua menemukan, mengembangkan, dan menganalisis alternatif yang nantinya bisa dilakukan, dan ketiga melakukan pemilihan dari alternatif yang telah ditemukan (Dicky, 2014).

Sementara itu pada proses pengambilan keputusan dapat dipengaruhi oleh beberapa faktor baik internal maupun eksternal. Beberapa faktor yang mempengaruhi keputusan petani dalam penanganan pasca panen lada putih di Kecamatan Simpang Teritip Kabupaten Bangka Barat adalah variabel jumlah produksi, persepsi harga dan kebutuhan konsumsi (Pranoto, 2016). Pada pengambilan keputusan petani mangga dalam sistem informal dengan pengumpul dipengaruhi oleh faktor-faktor umur petani, jumlah pohon, dan akses terhadap modal (Sulistyowati et al., 2013). Namun demikian tidak semua karakterisitik petani memiliki pengaruh yang signifikan terhadap keputusan petani. Hasil kajian (Anisah \& Hayati, 2017) menyatakan bahwa pendidikan tidak berpengaruh secara nyata terhadap pengambilan keputusan oleh petani cabe jamu di Kecamatan Bluto. Demikian juga dengan pengalaman yang belum tentu berpengaruh terhadap keputusan petani dalam memilih benih lokal dan impor bawang merah di Kabupaten Cirebon (Theresia et al., 2016).

Selain faktor kondisi karakteristik petani, faktor lain yang perlu mendapat perhatian adalah faktor produksi yakni jumlah pohon, tenaga kerja keluarga serta harapan petani terhadap harga yang layak. Oleh karena itu makalah ini mencoba membahas keputusan petani jambu air dalam hal penanganan pasca panen berdasarkan kepemilikan pohon, sumberdaya tenaga kerja dalam keluarga dan pekerjaan luar usahatani.

\section{METODE PENELITAN}

Metode penelitian yang digunakan pada penelitian ini adalah metode deskriptif. Metode deskriptif adalah sebuah metode penelitian yang digunakan untuk menggambarkan fenomena-fenomena yang ada, serta yang berlangsung saat ini atau pada saat lampau. Metode deskriptif tidak memanipulasi atau melakukan pengubahan pada variabel bebas, melainkan melakukan penggambaran suatu kondisi dengan apa adanya, penggambaran ini bisa secara individu maupun kelompok, dan metode ini menggunakan angka yang sesuai dengan fakta di lapangan (Hamdi \& Bahruddin, 2015).

Lokasi yang dipilih untuk penelitian keputusan petani terhadap penanganan pasca panen jambu air adalah Kecamatan Wonosalam, Kabupaten Demak. Lokasi ini 
dipilih berdasarkan pertimbangan bahwa Kecamatan Wonosalam merupakan salah satu sentra pengembangan jambu air di Kabupaten Demak dan sebagian petani sudah menerapkan SOP-Good Agriculture Practice (GAP) dalam budidaya jambu air.

Populasi petani dalam penelitian jambu air di daerah Kecamatan Wonosalam, Kabupaten Demak ada 3 gapoktan dipilih berdasarkan jumlah petani yang banyak dan merupakan sentra jambu air di Kecamatan Wonosalam. Gapoktan tersebut yaitu Sekar Tani Desa Mranak, Sido Maju Desa Sidomulyo, dan Tani Sentosa Desa Kendaldoyong. Jumlah seluruh petani tiga gapoktan sebanyak 1.091 petani yang tersebar di Sekar Tani Desa Mranak sebanyak 295 petani, Sido Maju Desa Sidomulyo sebanyak 511 petani, dan Tani Sentosa Desa Kendaldoyong sebanyak 285 petani. Penentuan jumlah sampel didasarkan pada tingkat kepercayaan $95 \%(\mathrm{Z}=1,96)$, keragaman $\left(\mathrm{S}^{2}=5 \%\right)$ dan derajat penyimpangan $(\mathrm{d}=5$ $\%)$. Rumus perhitungan jumlah sampel menurut (Sugiarto, 2003) adalah sebagai berikut:

$$
n=\frac{N Z^{2} S^{2}}{N d^{2}+Z^{2} S^{2}}
$$

Berdasarkan data populasi dan rumus tersebut maka didapatkan sampel sebanyak 72 orang petani. Penarikan sampel dilakukan secara acak berlapis proporsional dengan persebaran untuk masing-masing
Gapoktan yaitu 18 petani di Kendaldoyong, 20 petani di Mranak, dan 34 petani di Sidomulyo. Pembatasan masalah pada penelitian ini adalah data yang diambil merupakan data tahun 2019.

Untuk mempelajari pengaruh karakteristik intrinsik dari keputusan dan unit pengambilan keputusan yang terlibat dapat dianalisis menggunakan regresi logistik (Scott et al., 1991). Oleh karena itu analisis faktor-faktor yang mempengaruhi keputusan petani memilih sistem usahatani padi organik dianalisis menggunakan metode regresi logistik. Regresi logistik digunakan untuk mengukur hubungan antara satu variabel dependent (Y) yang bersifat dikotomus (memiliki nilai dengan dua kemungkinan) dengan variabelvariabel independent (X) dari jenis kualitatif dan kuantitatif. (Gujarati, 2003), menyusun persamaan regresi logistik untuk estimasi faktor-faktor yang berpengaruh terhadap variabel dependent katagorik sebagai berikut :

$$
\begin{aligned}
& P i=E\left(Y=1 \mid X_{i}\right)=\frac{1}{1+e^{-\left(\beta_{0}+\beta_{i} X_{i}\right)}} \ldots \\
& P i=\frac{1}{1+e^{-z_{i}}}=\frac{e^{z}}{1+e^{z}} \\
& 1-P i=\frac{1}{1+e^{z_{i}}} \\
& \frac{P i}{1-p i}=\frac{1+e^{z_{i}}}{1+e^{z_{i}}}=\frac{e^{z_{i}}}{1+e^{-z_{i}}}=e^{z_{i}} \\
& Z_{i}=\operatorname{Ln}\left(\frac{P i}{1-p i}\right)=\beta_{0}+\beta_{i} X_{i}+u i
\end{aligned}
$$

Keterangan :

$\begin{array}{lll}\mathrm{Ln} & =\text { Logaritma Natural } \\ \mathrm{Pi} & =\text { peluang } & \text { keputusan }\end{array}$ 
responden melakukan penanganan pasca panen jambu air

1-Pi

$$
\begin{aligned}
&= \text { peluang keputusan } \\
& \text { responden tidak melakukan } \\
& \text { penanganan pasca panen } \\
& \text { jambu air }
\end{aligned}
$$

$\beta_{0}, \beta_{1}, \ldots \beta_{\mathrm{i}}=$ hasil estimasi koefisien regresi logistik

Dalam hal penelitian keputusan petani terhadap penanganan pasca panen jambu air melibatkan tujuh variabel bebas yang akan diestimasi, sehingga persamaan regresi logistik dapat disusun sebagai berikut:

$$
\begin{aligned}
Z(x)= & \operatorname{In} \frac{P(x)}{1-P(x)}=\beta_{0}+\beta_{1} X_{1}+\beta_{2} X_{2}+ \\
& \beta_{3} X_{3}+\beta_{4} X_{4}+\beta_{5} X_{5}+\beta_{6} X_{6}+ \\
& \beta_{7} X_{7} \ldots \ldots \ldots \ldots \ldots \ldots \ldots \ldots \ldots \ldots \text { (7) }
\end{aligned}
$$

Keterangan:

$\mathrm{P}$

$$
\begin{aligned}
= & \text { peluang keputusan petani. } \\
& \text { Skala nominal: } 1= \\
& \text { melakukan penanganan } \\
\text { pasca panen; } 0=\text { Tidak } & \text { melakukan penanganan } \\
\text { pasca panen } &
\end{aligned}
$$

$\beta_{0}, \beta_{1}, . . \beta_{5}=$ koefesien parameter

$\mathrm{X}_{1} \quad=$ produksi $(\mathrm{kg})$

$\mathrm{X}_{2} \quad=$ umur petani (tahun)

$\mathrm{X}_{3} \quad=$ jumlah pohon (batang)

$\mathrm{X}_{4} \quad=\operatorname{harga}(\mathrm{Rp} / \mathrm{kg})$

$\mathrm{X}_{5} \quad=$ jumlah anggota keluarga (orang)

Dummy = pekerjaan luar usahatani $(\mathrm{D}$ $=1$ jika ada, $\mathrm{D}=0$ jika tidak ada)

Uji semua parameter serentak menggunakan uji likehood/uji $\mathrm{G}$ dan uji parameter secara persial menggunakan uji Wald. Untuk menguji pengaruh dari variabel bebas (produksi, luas lahan, jumlah pohon, umur petani, pendidikan, pengalaman dan pendapatan usahatani) terhadap variabel tidak bebas (peluang keputusan melakukan atau tidak melakukan penanganan pasca panen) menggunakan uji G. Uji ini bertujuan untuk mengetahui apakah terdapat pengaruh peubah-peubah bebas yang digunakan dalam model secara bersama-sama terhadap peubah respon. Uji $\mathrm{G}$ pada taraf kepercayaan $95 \%$. (Hendayana, 2015) merumuskan hal tersebut secara matematis dalam perhitungan menurut teori sebagai berikut :

$G=-2 \ln \left[\frac{\left(\frac{n o}{n}\right)^{n 1}\left(\frac{n o}{n}\right)^{n 0}}{\sum n i Y^{i}(1-\pi 1)^{(1-Y i)}}\right]$

Keterangan :

$\mathrm{n} 0=$ jumlah sempel yang termasuk dalam katagori $\mathrm{P}(\mathrm{Y}=1)$

$\mathrm{n} 1=$ jumlah sampel yang termasuk dalam katagori $\mathrm{P}(\mathrm{Y}=0)$

$\mathrm{n}=$ total jumlah sampel

Nilai G statistik mengikuti sebaran Chi-square $\left(\mathrm{X}^{2}\right)$, apabila nilai $\mathrm{G}$ statistik lebih besar dari nilai Chi-square $\left(\mathrm{X}^{2}\right)$ tabel atau nilai P-value lebih besar dari pada $\alpha$ maka $\mathrm{H}_{0}$ diterima atau $\mathrm{H}_{1}$ ditolak pada tingkat $\alpha$ tersebut.

Hipotesis dalam uji keseluruhan ini adalah :

$$
\mathrm{H}_{0}: \beta_{1}=\beta_{2}=\beta_{3}=\ldots=\beta \mathrm{n}=0
$$

$\mathrm{H}_{1}$ : minimal satu $\beta \mathrm{i} \neq 0$ dengan i $1,2,3, \ldots$.

Jika $G \geq\left(X^{2}\right)((\rho, \alpha))$ berarti $\mathrm{H}_{0}$ ditolak, artinya secara bersamaan produksi, umur, jumlah pohon, harga, jumlah anggota 
keluarga dan pekerjaan petani tidak berpengaruh terhadap keputusan petani melakukan atau tidak melakukan penanganan pasca panen jambu air.

Jika $\mathrm{G}<\left(\mathrm{X}^{2}\right)(\rho, \alpha)$ berarti $\mathrm{H}_{0}$ diterima, artinya secara bersamaan produksi, umur, jumlah pohon, harga, jumlah anggota keluarga dan pekerjaan petani berpengaruh terhadap keputusan petani melakukan atau tidak melakukan penanganan pasca panen jambu air.

Statistik Uji Wald (W) yang digunakan untuk menguji parameter $\beta i$ secara parsial didasarkan hipotesis: $H o: \beta i$ $=0$ lawan $H o: \beta i \neq 0(i=1,2,3, \ldots, p)$ (Scott et al., 1991). Pengujian masingmasing pengaruh variabel bebas terhadap variabel tidak bebas secara individual dengan menggunakan uji Wald. Perhitungan secara teoritis dapat menggunakan rumus berikut :

$$
\mathrm{Wi}=\frac{\beta \mathrm{i}}{S E(\beta \mathrm{i})} \text {. }
$$

Nilai uji Wald menyebar mengikuti sebaran normal (Z). Apabila $\mathrm{Z}$ hitungan lebih besar dari $\mathrm{Z}$ tabel atau P-value (sig) dari Wald test lebih besar dari a maka $\mathrm{H}_{0}$ diterima atau $\mathrm{H}_{1}$ ditolak pada tingkat $\alpha$ tersebut.

Hipotesis dalam uji persial adalah:

$$
\begin{aligned}
& \mathrm{H}_{0}: \beta \mathrm{i}=0 \\
& \mathrm{H}_{1}: \beta \mathrm{i} \neq 0
\end{aligned}
$$

Jika $W \geq Z \_(\alpha / 2)$ atau $p$ lebih dari $\alpha$ berarti Ho diterima, artinya secara parsial produksi, umur, jumlah pohon, harga, jumlah anggota keluarga dan pekerjaan petani tidak berpengaruh terhadap keputusan petani melakukan atau tidak melakukan penanganan pasca panen jambu air.

Jika $\mathrm{W}<\mathrm{Z}_{-}(\alpha / 2) \quad$ atau peluang kurang dari $\alpha$ berarti Ho ditolak, artinya secara parsial produksi, umur, jumlah pohon, harga, jumlah anggota keluarga dan pekerjaan petani berpengaruh terhadap keputusan petani melakukan atau tidak melakukan penanganan pasca panen jambu air.

Hasil dari estimasi model logit digunakan untuk pendugaan keputusan pemilihan petani terhadap penanganan pasca panen jambu air menggunakan rumus dalam persamaan (3).

\section{HASIL DAN PEMBAHASAN}

\section{Faktor-faktor yang Mempengaruhi Keputusan Petani}

Dalam penelitian ini faktor-faktor yang dibangun dalam model keputusan adalah produksi, jumlah pohon, umur petani, harga, jumlah anggota keluarga dan pekerjaan. Dalam hal ini pekerjaan terkait dengan bekerja di luar usahatani atau tidak. Secara deskriptif data variabel penentu keputusan petani tersebut disajikan dalam Tabel 1.

Berdasarkan Tabel 1 dapat diketahui bahwa produktivitas tanaman jambu rata- 
rata mencapai $91,66 \mathrm{~kg}$ per pohon per tahun dalam tiga kali panen. Dengan produksi sekitar 4,49 ton per tahun maka dapat diperkirakan bahwa penerimaan petani bisa mencapai Rp 48 juta per tahun. Hal ini mengindikasikan bahwa jambu merupakan komoditas potensial dan perlu penanganan serius agar hasilnya dapat memberikan pendapatan yang layak bagi para petani.

Hasil pengujian kelayakan model regresi logistik yang bertujuan untuk melihat apakah data empiris cocok dengan model (tidak ada perbedaan antara model dengan data) dapat dilihat dari nilai Hosmer and Lemeshow Goodness of Fit Test sebagaimana disajikan dalam Tabel 2 berupa nilai Chi-square.

Hasil uji Hosmer dan Lameshow menunjukkan bahwa nilai ChiSquare hitung sebesar 7,734<

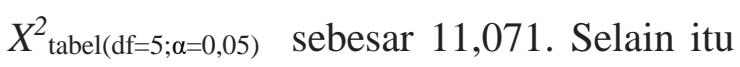
terlihat juga bahwa nilai statistic signifikansi $>0,05$. Berdasarkan hasil dapat disimpulkan bahwa ada tidak terdapat perbedaan secara signifikan antara model dengan nilai observasinya sehingga model keputusan yang disusun dapat diterima dan dapat dilakukan pengujian hipotesis.

Ketepatan model setelah variabel bebas di masukkan ke dalam model regresi logistik yang di bentuk dapat di lihat pada Tabel 3.

Hasil prediksi dengan tabel klasifikasi menunjukkan bahwa dari 29 petani sampel yang tidak melakukan penanganan pasca panen hanya ada 16 petani yang benar-benar tidak melakukan penanganan pasca panen jambu air sehingga dapat dikatakan ketepatan prediksi jumlah petani yang tidak melakukan penanganan pasca panen adalah sebesar $55,2 \%$. Sebaliknya jumlah petani yang benar-benar melakukan pasca panen adalah 36 dari 42 hasil observasi atau nilai prediksi sebesar $83 \%$. Dengan demikian model ini mampu memberikan nilai prediksi sebesar 72,2\%. Dengan kata lain penelitian ini memiliki ketepatan prediksi sebesar 72,2\%.

Tabel 1. Sebaran nilai faktor-faktor yang mempengaruhi keputusan petani

\begin{tabular}{lrrrr}
\hline Variabel & Minimum & Maksimum & \multicolumn{1}{c}{ Mean } & Std. Deviation \\
\hline Produksi (kg) & 52 & 14.000 & $4.491,35$ & 3619,48 \\
Jumlah pohon (batang) & 4 & 210 & 49,00 & 37,13 \\
Umur (tahun) & 39 & 69 & 53,53 & 8,25 \\
Harga (Rp/kg) & 7.600 & 17.000 & $10.736,00$ & 2482,64 \\
Jumlah keluarga (orang) & 2 & 6 & 3,75 & 1,03 \\
Pekerjaan offfarm & 0 & 1 & 0,24 & 0,43 \\
\hline
\end{tabular}

Tabel 2. Uji kelayakan model regresi logistik keputusan menggunakan Hosmer and Lameshow

\begin{tabular}{lrrr}
\multicolumn{1}{c}{ test } & & & \\
\hline Step & Chi-square & Df & Sig. \\
\hline 1 & 7,734 & 8 & 0,460 \\
\hline
\end{tabular}


p-ISSN: 1410-0029; e-ISSN2549-6786

Agrin Vol. 25, No. 1, April 2021

Tabel 3. Ketepatan model regresi logistik pada tabel klasifikasi setelah variabel bebas di masukkan kedalam model

\begin{tabular}{ccrrr}
\hline \multirow{2}{*}{ Observasi } & \multicolumn{3}{c}{ Prediksi } \\
& & P(keputusan) & \multicolumn{2}{c}{ Persentase } \\
& & Tidak =0 & Ya=1 & Benar \\
\hline \multirow{2}{*}{ P(keputusan) } & Tidak $=0$ & 16 & 13 & 55.2 \\
Ya $=1$ & 7 & 36 & 83.7 \\
Persentase keseluruhan & & & 72.2 \\
\hline
\end{tabular}

Tabel 4. Histori pendugaan model keputusan block 0 dan block 1

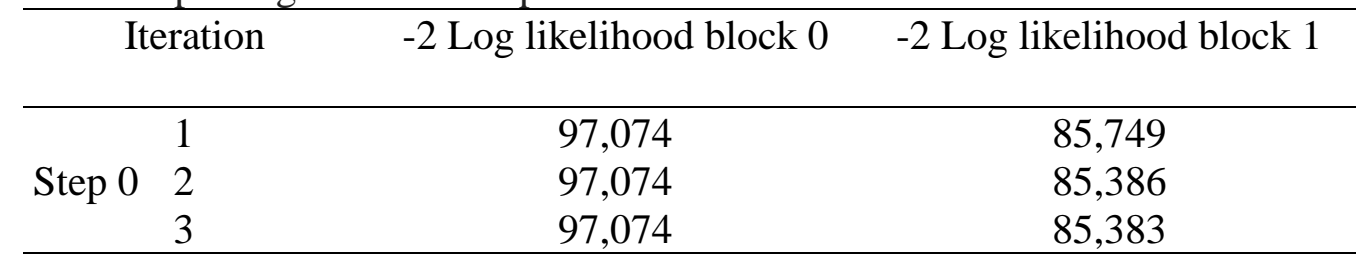

Hasil pendugaan model keputusan pada iterasi histori block 0 menunjukkan bahwa nilai -2 Log Likelihood sebesar 97,074 . Nilai lebih besar dibanding nilai Chi-square $\left(X^{2}\right)_{\text {tabel }(\mathrm{df}=71 ; \alpha=0,05)}=86,635$. Hal ini menunjukkan bahwa model sebelum memasukkan variabel independent adalah tidak fit dengan data. Berdasarkan hal tersebut maka analisis dilanjutkan dengan pendugaan model keputusan pada iterasi block 1. Sementara itu hasil pendugaan model keputusan pada iterasi histori block 1 maka diperoleh hasil nilai -2 Log Likelihood $(85,383)<X_{\text {tabel }(\mathrm{df}=66 ; \alpha=0,1)}$ $(85,965)$ sehingga menerima $\mathrm{H}_{0}$, maka menunjukkan bahwa model dengan memasukkan variabel independent adalah fit dengan data. Berdasarkan hasil iterasi block 0 dan block1 maka nilai uji $\mathrm{G}=$ $(97,074-85,383)=11,691$. Hasil ini sama dengan nilai Chi-square pada hasil uji Omnibus Koefisien Model Keputusan.

Berdasarkan hasil pengujian ombinus koefisien model keputusan diperoleh nilai Chi-square sebesar 11,690 > $X_{\text {tabel }(\mathrm{d} f=6 ; \alpha=0,1)}$ sebesar 10,645. Hasil ini menunjukkan bahwa penambahan variable bebas pada model keputusan dapat memberikan pengaruh nyata pada taraf kepercayaan 90 atau $p=0,10$ sehingga model yang disusun dapat dikatakan fit. Dengan kata lain variabel bebas secara Bersama-sama berpengaruh nyata terhadap keputusan petani dalam melakukan penanganan pasca panen jambu air. Oleh karena itu analisis model keputusan ini dapat dilanjutkan.

Tabel 5. Hasil pengujian Omnibus koefisien model keputusan

\begin{tabular}{llccc}
\hline & & Chi-square & df & Sig. \\
\hline \multirow{4}{*}{ Step 1 } & Step & 11,690 & 6 & 0,069 \\
& Block & 11,690 & 6 & 0,069 \\
& Model & 11,690 & 6 & 0,069 \\
\hline
\end{tabular}


Tabel 6. Hasil pengujian Pseudo R Square model keputusan

$\begin{array}{ccc}-2 \text { Log likelihood } & \text { Cox \& Snell R Square } & \text { Nagelkerke R Square } \\ 85,383^{\mathrm{a}} & 0,150 & 0,202\end{array}$

Tabel 7. Hasil pendugaan faktor-faktor yang mempengaruhi keputusan petani

\begin{tabular}{lccccccr}
\hline \multicolumn{1}{c}{ Variabel } & & \multicolumn{1}{c}{ B } & S.E. & Wald & df & Sig. & Exp(B) \\
\hline Produksi (kg) & X1 & 0,000 & 0,000 & 1,638 & 1 & 0,201 & 1,000 \\
Umur petani (tahun) & X2 & $-0,080^{* *}$ & 0,040 & 4,020 & 1 & 0,045 & 0,923 \\
Jumlah pohon (batang) & X3 & $-0,007$ & 0,011 & 0,439 & 1 & 0,507 & 0,993 \\
Harga produk (Rp/Kg) & X4 & $0,000^{*}$ & 0,000 & 2,814 & 1 & 0,093 & 1,000 \\
Jml anggota Kelg (org) & X5 & $-0,487$ & 0,316 & 2,376 & 1 & 0,123 & 0,615 \\
Dummy pekerjaan off-farm & D & $1,434^{*}$ & 0,810 & 3,136 & 1 & 0,077 & 4,196 \\
(1=ada, 0=tidak ada) & & & & & & & \\
Constant & C & 8,142 & 3,206 & 6,450 & 1 & 0,011 & 3437,464 \\
\hline
\end{tabular}

Keterangan : ** signifikan pada $p=0,01$, dan $*$ signifikan pada $p=0,05$.

Pada pengujian selanjutnya adalah analisis uji koefisiesn determinasi atau Pseudo $R$ Square dengan melihat nilai Negelkerke $R \quad$ Square. Nilai ini menunjukkan ketepatan model yang disusun dalam model keputusan ini.

erdasarkan hasil analisis Pseudo $R$ Square sebagaimana disajikan dalam Tabel 5 maka dapat dilihat nilai Negelkerke R Square sebesar 0,202. Hal ini menunjukkan bahwa model yang disusun memiliki ketepatan melakukan estimasi sebesar 20,2 persen. Dengan kata lain bahwa bahwa kemampuan variabel independent dalam menjelaskan variabel dependent adalah sebesar 20,2 \% dan sisanya sebesar 79,8\% adalah faktor lain di luar model yang menjelaskan variabel dependent. Oleh karena itu perlu penelusuran lebih detail berbagai faktor yang mungkin berpengaruh dalam mengembangkan model keputusan ini.
Hasil pengujian faktor-faktor yang berpengaruh terhadap keputusan petani dalam melakukan penanganan pasca panen jambu air dapat dilihat dari hasil uji wald yang disajikan pada Tabel 7. Tabel tersebut menyajikan pengaruh masih-masing faktor secara parsial terhadap keputusan petani.

Hasil analisis pendugaan faktorfaktor yang mempengaruhi keputusan petani dengan model regresi logistik menunjukkan bahwa keputusan petani dalam melakukan penanganan pasca panen jambu air dipengaruhi oleh umur, harga dan pekerjaan.

Sementara untuk produksi, jumlah pohon dan jumlah anggota keluarga tidak berpengaruh secara signifikan terhadap keputusan petani. Hal tersebut mengindikasikan bahwa keputusan petani dipengaruhi oleh kondisi internal petani yakni umur dan pekerjaan serta kondisi 
eksternal petani yakni harga serta komoditas yang diusahakan.

Variabel umur petani berpengaruh negatif pada tingkat kepercayaan $95 \%$. Nilai odd ratio atau $\operatorname{Exp}(\mathrm{B})$ faktor umur adalah 0,993. Hal ini menunjukkan bahwa semakin tua petani, maka keputusan untuk melakukan penanganan pasca panen makin turun. Jika usia petani meningkat satu tahun maka keputusan petani untuk melakukan penanganan pasca panen turun sebesar 0,993 kali. Jika dicermati dari karakteristik petani maka rata-rata umur petani sudah berkisar 53 tahun lebih. Usia ini termasuk usia menjelang lansia yang memungkinkan mengalami penurunan kemampuan secara fisik. Temuan ini sejalan dengan (Sulistyowati et al., 2013) bahwa keputusan petani mangga dalam sistem informal dengan pedagang pengumpul menyatakan bahwa bertambahnya umur dari petani mangga maka probabilitas petani mangga untuk mengolah lahannya sendiri akan turun sebesar $0,16 \%$.

Faktor harga produk jambu air merupakan faktor yang berpengaruh positif secara signifikan pada tingkat kepercayaan $90 \%$. Hal ini menunjukkan bahwa semakin tinggi harga produk yang dijual, maka keputusan petani untuk melakukan penanganan pasca panen semakin meningkat. Nilai odd ratio atau $\operatorname{Exp}(\mathrm{B})$ sebesar 1,000 menunjukkan bahwa jika harga produk jambu air meningkat satu rupiah, maka peluang keputusan petani untuk melakukan penanganan pasca panen akan meningkat sebesar satu kali. Hal ini mengindikasikan bahwa harga menjadi salah satu stimulan bagi petani untuk meningkatkan kualitas produksi jambu yang dihasilkan. Jika penanganan pasca panen dilakukan dengan baik maka akan meningkatkan kualitas produksi setidaknya jambu tidak cepat rusak sehingga petani tidak rugi saat harga tinggi.

Pada faktor pekerjaan, hasil analisis menunjukkan bahwa petani yang memiliki pekerjaan di luar usahatani cenderung lebih tinggi peluang keputusannya untuk melakukan penanganan pasca panen jambu air. Nilai odd ratio atau $\operatorname{Exp}(\mathrm{B})$ sebesar 4,196 menunjukkan bahwa petani yang memiliki pekerjaan luar usahatani peluang keputusan untuk melakukan penanganan pasca panen lebih tinggi 4,296 kali dibanding petani yang tidak memiliki pekerjaan di luar usahatani.

Petani yang memiliki pekerjaan di luar usahatani memiliki relasi yang relatif lebih luas dibanding jika tidak bekerja di luar usahatani. Relasi yang dibangun dengan bekerja di luar usahatani sebagai guru, pegawai negeri, dan pedagang akan memungkinkan memberikan tambahan wawasan dan pengalaman yang dapat berdampak pada kemampuan usaha yang lebih baik. Wawasan dan pengalaman akan memberikan informasi dan pengetahuan 
yang dapat menjadi sistem pendukung keputusan mereka. Dengan demikian dapat dikatakan bahwa sifat kosmopolitan petani berpengaruh positif terhadap keputusan petani sebagaimana hasil penelitian (Sudarko et al., 2020). Berbagai jenis pekerjaan di luar pertanian yang memiliki relasi dengan banyak orang dapat saling berbagi informasi dan pengalaman yang dapat mempengaruhi seseorang dalam pengambilan keputusan usahataninya.

\section{Peluang Pengambilan Keputusan Petani}

Peluang pengambilan keputusan petani untuk melakukan penanganan pasca panen jambu air dapat diprediksi berdasarkan hasil estimasi nilai koefisien regresi logistik. Berdasarkan hasil estimasi parameter koefisien pada analisis regresi logistik dan variabel yang signifikan $\left(\mathrm{C}, \mathrm{X}_{2}\right.$, $\mathrm{X}_{4}$ dan Dummy Pekerjaan) berpengaruh terhadap keputusan, maka model persamaan dapat dirumuskan sebagai berikut:

$$
\begin{aligned}
Z_{i}= & \operatorname{Ln}\left(\frac{P i}{1-p i}\right)=8,142-0,080\left(\mathrm{X}_{2}\right)+ \\
& 0,000\left(\mathrm{X}_{4}\right)+1,434 \mathrm{D}
\end{aligned}
$$

Hasil pendugaan peluang keputusan petani untuk melakukan penanganan pasca panen berkisar antara 0,8-37 persen dengan rata-rata nilai pendugaan peluang sebesar 7,13 persen. Hal ini menunjukkan bahwa peluang petani mengambil keputusan untuk melakukan penanganan pasca panen masih tergolong sangat rendah. Faktor usia petani menjadi salah satu faktor yang bisa menurunkan peluang keputusan untuk melakukan penanganan pasca panen karena sebagian besar petani termasuk usia lanjut.

Oleh karena itu perlu regenerasi petani dengan pelatihan wirausaha petani muda untuk penanganan pasca panen. Selain itu perlu pengembangan inovasi teknologi pasca panen yang menarik bagi generasi milenial.

\section{KESIMPULAN}

Faktor-faktor yang berpengaruh secara nyata terhadap keputusan petani dalam melakukan penanganan pasca panen jambu air antara lain usia petani berpengaruh terhadap penanganan pasca panen dalam hal inovasi teknologi digital, insentif harga produk menjadi daya tarik bagi petani untuk meningkatkan pengelolaan usahatani dalam penanganan pasca panen dan jaringan kerjasama untuk akses informasi teknologi pasca panen serta akses informasi pasar bagi pengembangan pasar jambu air.

\section{DAFTAR PUSTAKA}

Anisah, A., \& Hayati, M. (2017). Pengambilan keputusan petani untuk tetap berusahatani cabe jamu di Kecamatan Bluto, Sumenep. AGRARIS: Journal of Agribusiness and Rural Development Research, 3(2), 112-118. https://doi.org/10.181 96/agr. 3251.

Badan Pusat Statistik. (2015). Produksi 
tanaman buah-buahan dan sayuran tahunan Jawa Tengah-2010-2015. https://jateng.bps.go.id/statictable/20 17/02/24/1446/

Badan Pusat Statistik. (2020). Statistik Daerah Kabupaten Demak.

BPS. (2017). Jumlah tanaman yang menghasilkan dan produksi buah sayur tahunan di Jawa Tengah. https://jateng.bps.go.id/statictable/20 19/10/16/1765/

Cahyono, B. (2010). Sukses budidaya jambu air di pekarangan dan perkebunan. Andi Offset.

Dicky, N. (2014). Konsep data mining vs sistem pendukung keputusan. Deepublish.

Dinas Pertanian Kabupaten Demak. (2010). Standar Operasional Prosedur (SOP) jambu air Kabupaten Demak. Dinas Pertanian Kabupaten Demak.

Febrianti, M. (2012). Faktor-faktor yang mempengaruhi nilai perusahaan pada industri pertambangan di bursa efek Indonesia. Jurnal Bisnis Dan Akuntansi, 14(2), 141-156.

Gujarati, D. N. (2003). Student solutions manual for use with basic econometrics (4th ed.). McGraw Hill.

Hamdi, A., \& Bahruddin, E. (2015). Metode Penelitian Kuantitatif Aplikasi dalam Pendidikan. Deepublish.

Hendayana, R. (2015). Penerapan metode regresi logistik dalam menganalisis adopsi teknologi pertanian. Informatika Pertanian, 22(1), 1-9. https://doi.org/10.21082/ip.v22n1.20 13.p1-9.

Pranoto, S. Y. (2016). Faktor yang mempengaruhi keputusan petani terhadap hasil panen lada putih di Kecamatan Simpang Teritip
Kabupaten Bangka Barat. AGRARIS: Journal of Agribusiness and Rural Development Research, 2(1), 69-74. https://doi.org/10.18196/agr.2127.

Scott, A. J., Hosmer, D. W., \& Lemeshow, S. (1991). Applied logistic regression. In Biometrics (vol. 47, issue 4). John Wiley \& Sons. https://doi.org/10.230 7/2532419.

Setiarini, R. (2015). Faktor-faktor yang mempengaruhi produksi jambu air di Desa Wonosari Kabupaten Demak. Economics Development Analysis Journal, 4(3), 308-315. https://doi. org/10.15294/edaj.v4i3.14838.

Sudarko, S., Sumardjo, S., Fatchiya, A., \& Tjitropranoto, P. (2020). Pengaruh keputusan petani kopi rakyat dalam pemilihan sistem kopi organik dan non organik di Jawa Timur. Agriekonomika, 9(1), 1-15. https:// doi.org/10.21107/agriekonomika.v9i 1.6216 .

Sugiarto. (2003). Sampling Teknik. Gramedia Pustaka utama.

Sulistyowati, L., Natawidjaja, R. S., \& Saidah, Z. (2013). Faktor-faktor sosial ekonomi yang mempengaruhi keputusan petani mangga terlibat dalam sistem informal dengan pedagang pengumpul. Sosiohumaniora, 15(3), 285-293. https://doi.org/10.24198/sosiohumani ora.v15i3.5753.

Theresia, V., Fariyanti, A., \& Tinaprilla, N. (2016). Analisis persepsi petani terhadap penggunaan benih bawang merah lokal dan impor di Kabupaten Cirebon, Jawa Barat. Jurnal Penyuluhan, 12(1), 74-88. https://doi.org/10.25015/penyuluhan. v12i1.11324. 